\title{
Effect of the bur grit size on the flexural strength of a glass-ceramic
}

\section{(Efeito da granulação do instrumento de desgaste sobre a resistência flexural de uma vitrocerâmica)}

\author{
P. P. Kist ${ }^{1}$, I. L. Aurélio ${ }^{1}$, M. Amaral $^{2}$, L. G. May ${ }^{1}$ \\ ${ }^{I}$ School of Dentistry, Federal University of Santa Maria, R. Floriano Peixoto, 1184, Centro, \\ Santa Maria, RS, Brazil 97015-372 \\ ${ }^{2}$ School of Dentistry, University of Taubaté, Av. Granadeiro Guimarães, 270, Centro, Taubaté, SP, Brazil 12020-130 \\ priscilapkist@gmail.com,lamadridiana@homail.com,marinamaral_85@yahoo.com.br,liligmay@gmail.com
}

\begin{abstract}
The purpose of the present study was to determine the biaxial flexural strength (BFS) of a CAD/CAM leucite reinforced glassceramic ground by diamond burs of different grit sizes and the influence of surface roughness on the BFS. For this, 104 plates were obtained from CAD/CAM ceramic blocks and divided into 4 groups $(n=26)$, according to bur grit size: extra-fine, fine, medium and coarse. Roughness parameters ( $\mathrm{Ra}, \mathrm{Ry}_{\mathrm{Max}}$ ) were measured, and plates were kept dry for 7 days. The flexural test was carried out and BFS was calculated. Ra, $\mathrm{Ry}_{\mathrm{Max}}$ and BFS data were subjected to analysis of variance and post-hoc test. Weibull analysis was used to compare characteristic strength and Weibull modulus. Regression analysis was performed for BFS vs. Ra and Ry ${ }_{\text {Max }}$. When burs with coarse grit were used, higher surface roughness values were found, causing a negative effect on the ceramic BFS (117 MPa for extra-fine, and $83 \mathrm{MPa}$ for coarse). Correlation (r) between surface roughness and BFS was 0.78 for Ry $\mathrm{Max}_{\text {and }} 0.73$ for Ra. Increases in diamond grit size have a significant negative effect on the BFS of leucite-reinforced glass-ceramics, suggesting that grinding of sintered glass-ceramic should be performed using burs with the finest grit possible in order to minimize internal surface flaws and maximize flexural strength.
\end{abstract}

Keywords: IPS Empress CAD, leucite, grinding, surface roughness, flexural strength.

\section{Resumo}

O estudo objetivou verificar a resistência flexural biaxial (RFB) de uma vitrocerâmica reforçada por leucita totalmente sinterizada, após desgaste com brocas diamantadas de diferentes granulações, e analisar a correlação desses valores com a rugosidade gerada na superficie desgastada. Para isso, 104 pastilhas obtidas a partir de blocos cerâmicos para CAD/CAM foram divididas em 4 grupos $(n=26)$ de acordo com as diferentes granulações dos instrumentos de desgaste: extrafina, fina, média e grossa. Os parâmetros de rugosidade Ra e Ry ${ }_{\text {Max }}$ foram medidos e as amostras foram mantidas a seco por 7 dias. Ensaio de flexão foi realizado conforme a ISO 6872 e a RFB foi calculada. Dados de RFB, Ra e Ry ${ }_{\text {Max }}$ foram submetidos à análise de variância Kruskal-Wallis e teste LSD para comparação das médias. Análise de Weibull foi realizada para comparação da resistência característica e módulo de Weibull

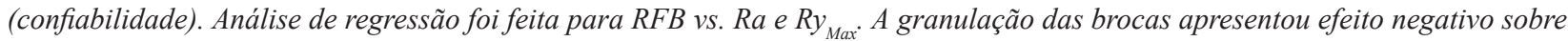
a RFB da cerâmica (117 MPa para extrafina e 83 MPa para grossa). A correlação (r) entre rugosidade superficial e RFB foi de 0,78 para $R y_{\text {Max }}$ e de 0,73 para Ra. A granulação das brocas tem um efeito significativo na resistência flexural de cerâmicas vítreas totalmente sinterizadas. Logo o corte deve ser realizado com instrumentos de menor granulação possível, a fim de minimizar irregularidades superficiais e otimizar a resistência estrutural.

Palavras-chave: IPS Empress CAD, leucita, desgaste, rugosidade superficial, resistência flexural.

\section{INTRODUCTION}

Due to their undeniable aesthetic advantages and excellent mechanical properties, dental ceramics have undergone substantial development in recent decades. These materials have been widely used for fixed dental prostheses, especially with the advent of automated systems for CAD/ CAM (computer aided design/computer aided machining) [1]. However, they are brittle materials that do not withstand permanent deformation, and under tension result in propagation of cracks, starting from flaws on the surface or inside the material [2]. The tensile strength of a ceramic material is much lower than its compressive strength [3], thus failures will normally occur from the inner surface of ceramic crowns, where tensile stresses are concentrated, toward the loaded surface (occlusal). The fracture strength of ceramics depends on the size, type, and distribution of failures in the bulk or on the surface of the material, as well as on their fracture toughness and on the environmental humidity [4]. The influence of water associated with cyclic loading is responsible for failures in dental ceramics after some years in service [5]. On the other hand, immediate failure that occurs during the restoration try-in or within a few hours or days after cementation is likely to originate from a 
major processing flaw. This includes pores and the presence of residual mechanical and thermal stresses accumulated during the fabrication process or after machining [5].

Adjustments of ceramic restorations, involving clinical grinding procedures, as well as machining in CAD-CAM systems, are usually performed with diamond burs, which present several grit sizes and produce different patterns of surface roughness [6]. The diamond that comes into contact with the ceramic acts as a sharp indenter, creating irregular geometries and inducing plastic deformations and radial/ lateral cracks, resulting in material removal and surface and subsurface damage $[7,8]$. According to some studies, grinding decreases the fracture strength of dental ceramics [9-11], due to the incorporation of surface irregularities or defects, which concentrate stresses and favor propagation of cracks. The speed and depth of the grind seem not to have a significant effect $[12,13]$, however, changes in the uniformity and grit size of the diamond particles influence characteristics of the grinding surfaces [14]. Studies have demonstrated that surface roughness and flaw size caused by different grinding/polishing procedures have an indirect relationship to the ceramic flexural strength $[6,15,16]$. Therefore, the purpose of this study was to determine the biaxial flexural strength of a sintered CAD/CAM leucitereinforced glass-ceramic, as a function of the surface roughness, induced by grinding with diamond burs of different particle diameters (coarse, medium, fine and extrafine). The hypotheses are: 1) grinding tools with finer grit sizes could produce higher values of flexural strength, and 2) flexural strength is associated with the surface roughness produced by grinding.

\section{MATERIALS AND METHODS}

\section{Sample preparation}

A total of 104 plates were obtained from leucitereinforced glass-ceramic blocks of IPS Empress ${ }^{\circledR}$ CAD, L12 Ivoclar/Vivadent. The blocks (12 mm x $10 \mathrm{~mm}$ x $25 \mathrm{~mm}$ ) were sectioned with a diamond disc (Isomet 1000, Buehler, Lake Bluff, IL, USA), and slices of $12 \mathrm{~mm} \times 10 \mathrm{~mm} \times 1.8$ $\mathrm{mm}$ were obtained. The upper surface of each specimen

Table I - Experimental groups according the bur grit size used for grinding $(\mathrm{n}=26)$.

[Tabela I - Grupos experimentais de acordo com a granulação das brocas diamantadas utilizadas para o desgaste da cerâmica $(n=26)$.]

\begin{tabular}{ccc}
\hline Group & Bur grit & $\begin{array}{c}\text { Particle diameter } \\
\text { (KG Sorensen, } \\
\text { S. Paulo, Brazil) }\end{array}$ \\
\hline XF & Extra-fine & $30 \mu \mathrm{m}$ \\
F & Fine & $50 \mu \mathrm{m}$ \\
M & Medium & 90 to $120 \mu \mathrm{m}$ \\
$\mathrm{C}$ & Coarse & $150 \mu \mathrm{m}$ \\
\hline
\end{tabular}

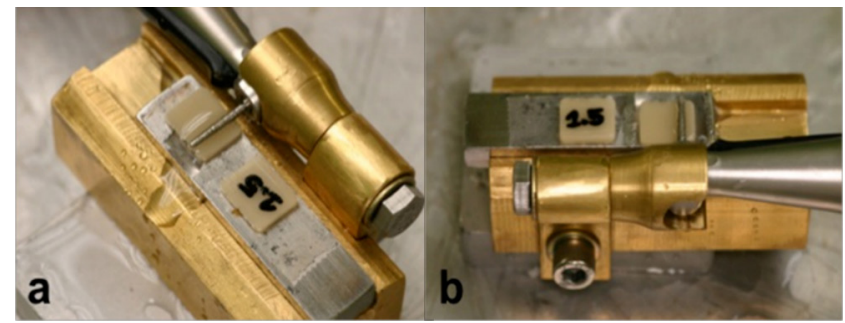

Figure 1: Images of the device used for the adjustment of the bur position (height and parallelism), in order to obtain uniform grinding. A $1.5 \mathrm{~mm}$-thick standard tab was used for the control of the specimens' final thickness.

[Figura 1: Imagens do dispositivo confeccionado para controle de altura e inclinação da broca, a fim de obter um corte uniforme. Um espécime padrão de 1,5 $\mathrm{mm}$ de espessura foi usado para controlar a espessura final.]

was finished to the thickness of $1.6 \mathrm{~mm}$ by grinding with silicon-carbide waterproof sandpaper (\#280, 400 and 600), and the plates were randomly divided into 4 groups $(n=26)$ (Table I). Unfinished faces of the specimens were abraded with tapered diamond burs (\#4138, KG Sorensen, Cotia, Brazil) under the same speed and irrigation, according to the different groups: XF (extra-fine), F (fine), M (medium) and C (coarse).

The polished sides of the specimens were fixed with a double-side tape on a sliding bar (Fig. 1), which was part of a customized device for holding the hand piece (T2 Revo R 170 IS, Sirona, Bensheim, Germany) and keeping the diamond bur parallel to the surface of the plate. Uniform wear at a constant speed under abundant water irrigation was performed on the entire length of the specimen (opposite to the polished side) to the thickness of $1.5 \mathrm{~mm}$. Burs were changed every 3 plates. Then, the specimens were cleaned in an ultrasonic bath for $2 \mathrm{~min}$, and the thickness was measured in the center of each specimen with a digital micrometer (Starret $^{\circledR} 210$ MAP, Massachussetts, USA).

\section{Surface roughness analysis}

All specimens were analyzed with a contact profilometer (SJ 210, Mitutoyo, Japan). Three readings of Ra and Ry parameters were performed for each specimen, transversally to the bur marks, according to ISO 4287/1997 [17]. Ra expresses the average roughness and Ry expresses the larger amplitude within the profile [18, 19]. Measurements were performed with $\lambda \mathrm{c}=0.8 \mathrm{~mm}(0.1<\mathrm{Ra} \leq 2.0)$ and total measuring length of $4 \mathrm{~mm}$. Gaussian filter was employed for separation of defects in the shape of the roughness profile. For Ra parameter, the arithmetic mean of the three readings was calculated; for Ry, the maximum value of the three Ry measurements was used, expressing the "Ry ${ }_{\text {Max }}$ " parameter.

\section{Biaxial flexure test}

Specimens were kept at room-temperature conditions for one week and then subjected to a biaxial flexure strength 
test according to ISO 6872/2008 [20], in a universal testing machine (EMIC, São José dos Pinhais, PR, Brazil) at 0.5 $\mathrm{mm} / \mathrm{min}$. Before the test, adhesive tape was fixed on the compression side of the discs to avoid the spreading of the fragments [21] and to provide better contact between the piston and the specimen [22]. Values of load to fracture (N) were used to calculate the flexural strength (MPa), considering the thickness of the plates, according the following Equations $\mathrm{A}, \mathrm{B}$ and $\mathrm{C}$ :

$$
\begin{aligned}
& \sigma=-0.2387 \mathrm{P} \frac{(\mathrm{x}-\mathrm{y})}{\mathrm{b}^{2}} \\
& \mathrm{X}=(1+v) \ln \left(\frac{\mathrm{r}_{2}}{\mathrm{r}_{3}}\right)^{2}+\frac{(1-v)}{2}\left(\frac{\mathrm{r}_{2}}{\mathrm{r}_{3}}\right)^{2} \\
& \mathrm{Y}=(1+v)\left[1+\ln \left(\frac{\mathrm{r}_{1}}{\mathrm{r}_{3}}\right)^{2}\right]+(1-v)\left(\frac{\mathrm{r}_{1}}{\mathrm{r}_{3}}\right)^{2}
\end{aligned}
$$

where $\sigma$, the maximum center tensile stress (MPa); $\mathrm{P}$, the fracture load $(\mathrm{N})$ (fracture load added to the weight of the piston); $b$, the plate thickness at fracture origin (mm); $v$, the Poisson's ratio (0.25); $r_{1}$, the radius of the support circle (4 $\mathrm{mm}) ; r_{2}$, the radius of the piston $(0.86 \mathrm{~mm}) ; r_{3}$, the radius of the specimens $(\mathrm{mm})$. For rectangular specimens used in this study, $r_{3}$ is given by $\ell(1+\sqrt{2}) / 2$, where $\ell$ is half of the average length of the rectangle sides [23].

\section{Statistical analyses}

Flexural strength and surface roughness data were analyzed regarding normality (Shapiro-Wilk) and homogeneity (Levene) of distribution. The Kruskal-Wallis and LSD (5\% significance) tests were set to compare means, since there was neither normal distribution nor homoscedasticity among the groups. Weibull analysis was used to compare the groups, regarding their characteristic strength $\left(\sigma_{0}\right)$ (strength occurring at a probability of failure of $63.2 \%$ ) and Weibull modulus $(m)$ (estimate of the reliability of the material). This analysis was conducted according to the Equation D:

$$
\mathrm{P}_{\mathrm{f}}=1-\exp \left[-\left(\frac{\sigma}{\sigma_{0}}\right)^{\mathrm{m}}\right]
$$

where, $P_{f}$ is the cumulative probability of failure; $\sigma$, the strength of the material in a certain $\mathrm{P}_{\mathrm{f}}$ (tension to fracture); $m$, the Weibull modulus; and $\sigma_{0}$, the characteristic strength. The probability of failure for each tension value $\left(\mathrm{P}_{\mathrm{f}(\mathrm{\sigma ij}}\right)$ was calculated using the Equation E:

$$
\mathrm{P}_{\mathrm{f}}=\frac{(\mathrm{i}-0.5)}{\mathrm{N}}
$$

where, $i$ is the ranking of the strengths from a group $(1,2,3$, $4 \ldots i$ th), and $N$ is the total number of specimens.

In addition, a regression analysis was performed considering first, $\mathrm{Ry}_{\mathrm{Max}}$ and $\mathrm{Ra}$ as independent variables and the flexural strength as dependent variable; and second, flexural strength as the independent variable and the number of fragments after fracture as dependent variable, according to the following Equation F:

$$
\mathrm{Y}=\mathrm{aX}+\mathrm{b}
$$

where $Y$ is the dependent variable, $a$ is a constant representing the angular coefficient, $X$ is the independent variable and $b$ is a second constant representing the intercept of the line with the vertical axis.

\section{RESULTS}

Kruskal-Wallis and post hoc LSD tests $(\alpha=0.05)$ were used to compare the final roughness values $\left(\mathrm{Ry}_{\mathrm{Max}}\right.$ and $\left.\mathrm{Ra}\right)$ among the experimental groups, since the data presented non-normal distribution for $\mathrm{XF}$ and $\mathrm{F}$ groups in relation to $\mathrm{Ry}_{\mathrm{Max}}$ parameter $(\mathrm{p}=0.000$ and $\mathrm{p}=0.003$, respectively, based on the Shapiro-Wilk test), and also heterogeneity of variances for Ra values $(\mathrm{p}=0.000$ based on the Levene test). Flexural strength data were analyzed by the same tests, due to heterogeneity of variances $(\mathrm{p}=0.044$ based on the Levene test).

According to Table II, when burs with coarser grits were used, higher surface roughness values were found, causing a negative effect on the ceramics' flexural strength.

Table II - Mean values (standard deviation) for surface roughness $\left(\mathrm{Ry}_{\mathrm{Max}}, \mathrm{Ra}\right)$ and flexural strength, and number of fragments of each specimen obtained after flexural test. Different letters indicate statistical difference ( $<0.05$; LSD test).

[Tabela II - Valores médios (desvio-padrão) de rugosidade superficial $\left(R y_{M a x}, R a\right)$ e de resistência flexural biaxial, e número de fragmentos obtidos após fratura dos espécimes. Letras diferentes indicam diferença estatística ( $p<0,05$; post hoc LSD).]

\begin{tabular}{ccccc}
\hline Group & $\operatorname{Ry}_{\text {Max }}(\mu \mathrm{m})$ & $\operatorname{Ra}(\mu \mathrm{m})$ & Biaxial flexural strength (MPa) & Number of fragments \\
\hline $\mathrm{XF}$ & $7.1(2.3)^{\mathrm{a}}$ & $0.9(0.2)^{\mathrm{a}}$ & $117(14)^{\mathrm{a}}$ & $2(12 \%), 3(42 \%), 4(27 \%), 5(12 \%)$, \\
$\mathrm{F}$ & $11.8(3.2)^{\mathrm{b}}$ & $1.7(0.2)^{\mathrm{b}}$ & $109(13)^{\mathrm{b}}$ & $6(4 \%), 7(4 \%)$ \\
$\mathrm{M}$ & $21.0(5.3)^{\mathrm{c}}$ & $3.2(0.7)^{\mathrm{c}}$ & $86(11)^{\mathrm{c}}$ & $2(31 \%), 3(46 \%), 4(23 \%)$ \\
$\mathrm{C}$ & $21.6(6.9)^{\mathrm{c}}$ & $3.7(1.3)^{\mathrm{d}}$ & $83(10)^{\mathrm{c}}$ & $2(81 \%), 3(19 \%)$ \\
\hline
\end{tabular}




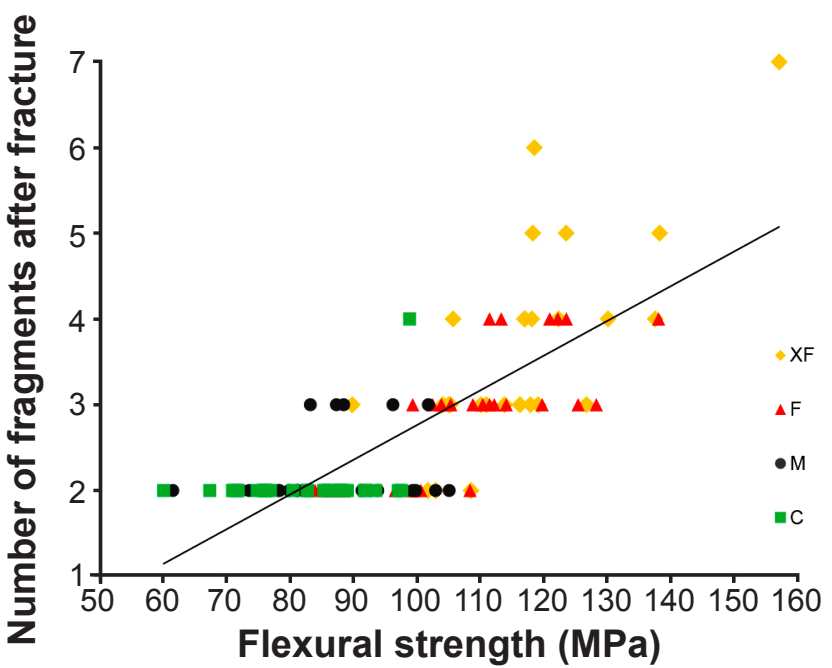

Figure 2: Linear regression for flexural strength vs. number of fragments after fracture.

[Figura 2: Gráfico de regressão linear para resistência flexural vs. número de fragmentos após a fratura dos espécimes.]

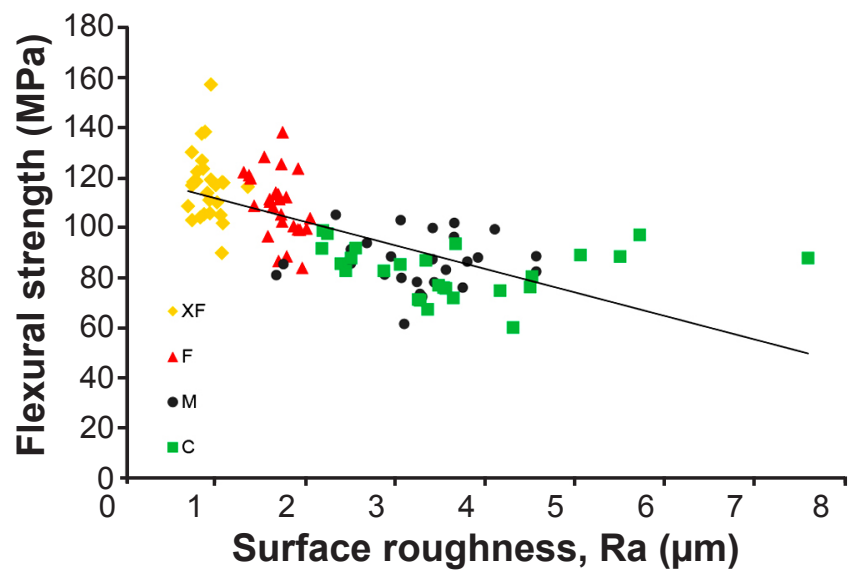

Figure 3: Linear regression for biaxial flexural strength $v s$. Ra. [Figura 3: Gráfico de regressão linear para resistência flexural biaxial vs. Ra.]

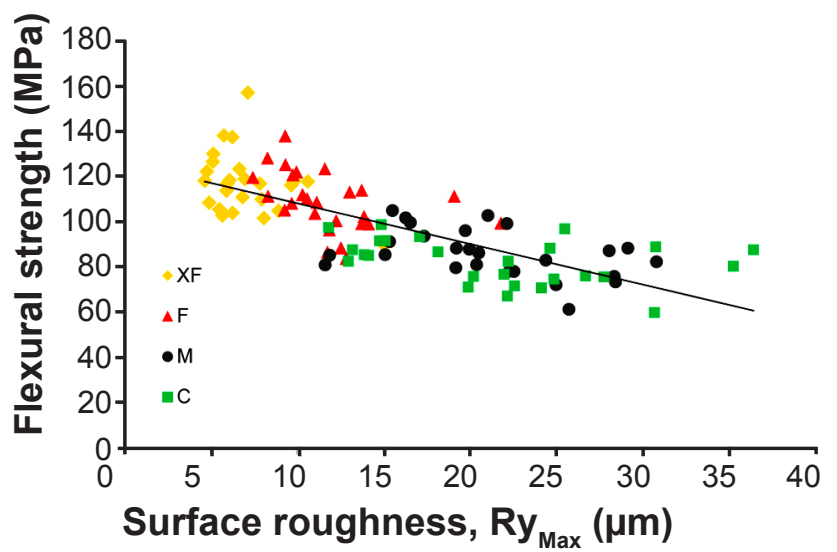

Figure 4: Linear regression for biaxial flexural strength vs. $\mathrm{Ry}_{\mathrm{Max}}$. [Figura 4: Gráfico de regressão linear para a resistência flexural biaxial vs. $R y_{\text {Max. }}$ ]

\section{Flexural strength (MPa)}

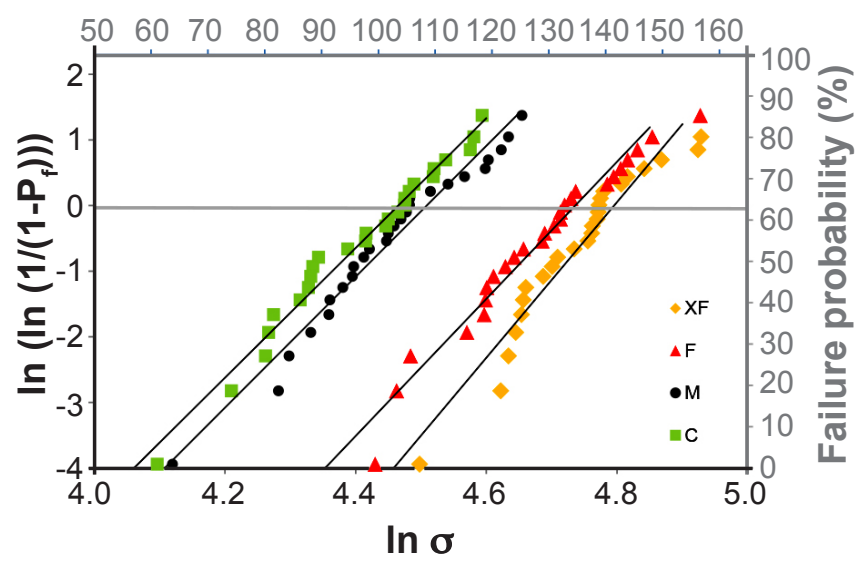

Figure 5: Weibull distribution for failure probability $v s$. failure stress in specimens, ground with different bur grits: coarse (C), medium (M), fine (F) and extra-fine (XF).

[Figura 5: Distribuição de Weibull para probabilidade de falha vs tensão de fratura nos espécimes cortados com brocas de granulações grossa $(G)$, média $(M)$, fina $(F)$ e extrafina $(F F)$.]

Table III - Values for coefficient of correlation (R), coefficient of determination $\left(\mathrm{R}^{2}\right)$, regression equation, and $p$-value for linear regression analysis between variables roughness $\left(\mathrm{Ra}\right.$ and $\left.\mathrm{Ry}_{\mathrm{Max}}\right)$ vs. biaxial flexural strength.

[Tabela III - Valores do coeficiente de correlação de Pearson (R), coeficiente de determinação $\left(R^{2}\right)$, equação de regressão e valor de p para as análises de regressão linear entre as variáveis de rugosidade (Ra e $R y_{M a x}$ ) vs. resistência flexural biaxial.]

\begin{tabular}{ccccc}
\hline Variables & $\mathrm{R}$ & $\mathrm{R}^{2}$ & Regression equation & $p$ \\
\hline Flexural strength $v s \mathrm{Ra}$ & -0.73 & 0.54 & $\mathrm{y}=-5.37 \mathrm{x}+114.82$ & $<0.05$ \\
Flexural strength $v s \mathrm{Ry}_{\text {Max }}$ & -0.78 & 0.60 & $\mathrm{y}=-6.03 \mathrm{x}+194.98$ & $<0.05$ \\
\hline
\end{tabular}

By comparing the flexural strength results from $\mathrm{C}$ and $\mathrm{XF}$ groups, it can be seen that there was an increase of $41 \%$ in flexural strength when XF grit burs were used. The number of fragments was lower for the C group ( $96 \%$ of the specimens fractured in 2 fragments), which also presented the lowest value of flexural strength. For F and XF groups, the majority of the specimens were fractured into 3 or more pieces. Linear regression analysis for the number of fragments $v s$. flexural strength showed a correlation coefficient $(\mathrm{R})$ of 0.77 , which indicates a positive and significant correlation between the variables, as shown in Fig. 2. 
The results of the regression analysis between flexural strength and ceramic surface roughness are shown in Table III and Figs. 3 and 4. Significant correlation coefficients were found between the flexural strength and surface roughness, due to grinding $\left(\mathrm{R}=-0.73\right.$ for $\mathrm{Ra}$; $\mathrm{R}=-0.78$ for $\left.\mathrm{Ry}_{\text {Max }}\right)$. These values represent the intensity of the linear relationship between the two variables in question. Furthermore, in this case, as the surface roughness increases, the flexural strength decreases. The coefficients of determination $\left(\mathrm{R}^{2}\right)$ for $\mathrm{Ra}$ and $\mathrm{Ry}_{\text {Max }}$ indicate that $54 \%$ and $60 \%$ of the variation in flexural strength were influenced by the variation of surface roughness, respectively. The characteristic strength $\left(\sigma_{0}\right)$ was higher when the ceramic was ground with $\mathrm{F}(113.96 \mathrm{MPa})$ and XF grit $(120.95 \mathrm{MPa})$, with no significant difference between these groups (Fig. 5). XF group was the group with the highest value of Weibull modulus ( $m=11.87$ ) (Table IV). However, there were no significant differences between the groups for this parameter.

Table IV - Values for characteristic strength $\left(\sigma_{0}\right)$, Weibull modulus $(m)$, and respective confidence intervals $(\mathrm{CI})$ for the different groups. 95\% CI - overlapping indicates no significant difference.

[Tabela IV - Valores de resistência característica, módulo de Weibull e respectivos intervalos de confiança (CI) dos diferentes grupos. Sobreposição dos intervalos de confiança (CI=95\%) indica não haver significância estatística.]

\begin{tabular}{ccc}
\hline Group & $\sigma_{0}(\mathrm{MPa})(\mathrm{CI}=95 \%)$ & $m(\mathrm{CI}=95 \%)$ \\
\hline $\mathrm{XF}$ & $120.9(116.2-125.7)$ & $11.9(8.05-15.7)$ \\
$\mathrm{F}$ & $114.0(108.9-119.1)$ & $10.5(7.09-13.6)$ \\
$\mathrm{M}$ & $90.81(86.61-95.09)$ & $9.97(6.76-13.0)$ \\
$\mathrm{C}$ & $86.93(82.87-91.07)$ & $9.88(6.70-12.9)$ \\
\hline
\end{tabular}

\section{DISCUSSION}

The main purpose of this study was to determine the biaxial flexural strength of a sintered CAD/CAM leucite-reinforced glass-ceramic as a function of the surface roughness induced by diamond burs with different particle diameters (coarse, medium, fine and extra-fine). Specimens ground with extrathin burs showed statistically higher flexural strength than those grind by burs with medium and coarse grits (Table I), confirming the first hypothesis. Grinding with coarser bur grits induced failures at lower strength levels (Table IV), producing fewer fragments (Table II). The number of fragments that resulted from the fracture of the specimens during the flexural strength must also be taken into account to show how much total cumulative energy is required to generate the fracture of a vitreous body as this energy is greater when more fragments are obtained [21]. It is noteworthy that the highest value of flexural strength was found for group XF, which presented 5, 6 and even 7 fragments after fracture.

Hung et al. [11] used a 170-grit coarse diamond bur to mimic clinical grinding on specimens of lithium disilicate (Empress 2). It was found that this procedure significantly reduces the flexural strength of the ceramic (from 283.2 MPa for the control group to $233.7 \mathrm{MPa}$ for the ground group). In CAD-CAM systems, machining process is made with diamond burs that present granulation of 50 to $60 \mu \mathrm{m}$ [24] corresponding to F granulation (Table I). Although apparently presenting more regular diamond grains, it may induce defects and lead to substantial degradation in the ceramic's strength $[14,25]$. According to [6], the surface roughness has a crucial role in the resistance of ceramics, unless the structure inherent to the material creates a higher stress concentration within it. Surface roughness produces a peak-valley distance, which can reach a critical defect size, interfering in the material's flexural strength [26]. Thus, larger defects, generated by burs with larger particle sizes may result in a lower resistance of the ceramic. Nakamura et al. [16] also found this relationship when they observed the influence of roughness produced by grinding with different sandpaper grits on the flexural strength of ceramics. In this sense, the finding that flexural strength was associated with surface roughness/damage produced by grinding supported the second hypothesis. The coefficient of the determination $\left(\mathrm{R}^{2}\right)$ between fracture strength and surface roughness $\left(\mathrm{Ry}_{\mathrm{Max}}\right)$ of the ceramic was 0.60 (Fig. 4), expressing a moderate relationship between the variables ( $60 \%$ of flexural strength can be explained by the variation in $\left(\mathrm{Ry}_{\mathrm{Max}}\right)$. The relationship between the roughness expressed by the fracture strength and $\mathrm{Ra}$ also resulted in a moderate coefficient of determination $\left(\mathrm{R}^{2}=0.54\right)$. According to [6], the microcracks commonly present in the ceramic surface could hardly be detected by the indenter of the profilometer because the tip is larger than the average size of these cracks (in the order of $3 \mu \mathrm{m})$. These cracks have a random orientation distribution and may remain unchanged throughout the service life of the material, but surface roughness serves as points of high stress concentration, which may lead to the propagation of these cracks at lower levels of strength, especially if the grooves present a perpendicular orientation to the axis of tensile.

In the present study, it was also found that the parameter $R y_{\text {Max }}$ showed a higher coefficient of determination $\left(R^{2}=0.60\right)$, when compared to the parameter $\mathrm{Ra}\left(\mathrm{R}^{2}=0.54\right)$. The difference between the parameters is probably related to the fact that the first $\left(\mathrm{Ry}_{\mathrm{Max}}\right)$ indicates the size of the largest flaw of the profile, which could be closer to the critical defect size of the ceramic. Furthermore, Ra values show an average value relative to all surface defects (average roughness). If a non-typical peak or valley appears on the surface, the mean value (Ra) would not change significantly [27]. This particularity may lead to somewhat of an underestimation of the critical defects that are existent in the specimen surfaces. An examination of the characteristic strength parameter showed higher strength values for the specimens that were ground with finer instruments (F, XF). In terms of reliability $(m)$ there was no difference between the groups since the confidence intervals overlapped, indicating a similar variability in the different groups. Curtis et al. [28] examined the influence of precementation surface modification techniques, namely alumina abrasion and surface grinding. The coarse grinding regime significantly reduced both the bi-axial flexure strength and 
the associated $m$, compared to the control. It was suggested that coarse grinding significantly reduced the bi-axial flexure strength and $m$ due to the increased surface roughness.

The high correlation between strength $v s$. number of fragments, as well as the roughness vs. strength, indicates that the flexural test used showed adequate sensitivity to the analyzed factor. Moreover, the results found in this research are in agreement with the cited literature and may help in understanding the effect that grinding with diamond burs has on the strength of leucite-reinforced glass-ceramics restorations. Considering the results, it can be hypothesized that the use of instruments with fine grits, smaller than those used in this study, could further favor the structural strength of glass-ceramics. It is suggested that subsequent studies be performed to test this hypothesis and to assess whether there is clinical relevance for using such instruments for external and, mostly, internal finishing of glass-ceramics in automated systems. The machining systems could be improved in order to allow this finishing to be performed by the milling machine itself, resulting in a reduction of the critical defects on the restoration surface. Studies could also be conducted to ascertain the influence of aging and water contact in the slow crack growth phenomenon on tensile strength of ground glass-ceramics.

\section{CONCLUSIONS}

The surface roughness induced by burs with large particle sizes has a negative effect on the flexural strength of sintered glass-ceramics. This suggests that adjustments of sintered glass-ceramic should be performed using burs with the finest grit possible, in order to minimize the restoration's surface roughness, avoiding stress concentration, and maximizing the flexural strength.

\section{ACKNOWLEDGEMENTS}

The authors thank the Department of Biomaterials and Oral Biology, School of Dentistry, University of S. Paulo and Center for Health Sciences/Federal University of Santa Maria for supporting this research. Also, we are grateful to Ivoclar Vivadent and KG Sorensen for material donation. The authors claim no conflict of interest.

\section{REFERENCES}

[1] A. Shenoy, N. Shenoy, "Dental ceramics: an update", J. Conserv. Dent. 4 (2010) 195-203.

[2] K.J. Anusavice, R.W. Phillips, Phillips' science of dental materials, $11^{\text {th }}$ Ed., Saunders, St Louis (2003).

[3] J.L. Ferracane, Materials in dentistry: principles and applications, $2^{\text {nd }}$ Ed., Lippincott Williams \& Wilkins, Philadelphia (2001).

[4] J.R. Kelly, "Dental ceramics: current thinking and trends", Dent. Clin. N. Am. 48 (2004) 513-530.

[5] I.L. Denry, "How and when does fabrication damage adversely affect the clinical performance of ceramic restorations?", Dent. Mater. 1 (2013) 85-96.

[6] N. De Jager, A.J. Feilzer, C.L. Davidson, "The influence of surface roughness on porcelain strength", Dent. Mater. 16 (2000) 381-388.

[7] L. Yin, X.F. Song, Y.L. Song, T. Huang, J. Li, “'An overview of in vitro abrasive finishing \& $\mathrm{CAD} / \mathrm{CAM}$ of bioceramics in restorative dentistry", Int. J. Mach. Tool. Manu. 46 (2006) 1013-1026.

[8] D. Rekow, V.P. Thompson, "Engineering long-term clinical success of advanced ceramic prostheses", J. Mater. Sci: Mater. Med. 18 (2007) 47-56.

[9] R.G. Luthardt, M. Holzhüter, O. Sandkuhl, V. Herold, J.D. Schnapp, E. Kuhlisch, M. Walter, "Reliability and properties of ground Y-TZP-zirconia ceramics", J. Dent. Res. 7 (2002) 487-491.

[10] M.N. Aboushelib, H. Wang, "Effect of surface treatment on flexural strength of zirconia bars", J. Prosthet. Dent. 104 (2010) 98-104.

[11] C.Y. Hung, Y.L. Lai, Y.L. Hsieh, L.Y. Chi, S.Y. Lee, "Effects of simulated clinical grinding and subsequent heat treatment on microcrack healing of a lithium disilicate ceramic", Int. J. Prosthodont. 21 (2008) 496-498.

[12] L. Yin, F.X. Song, F.S. Qu, G.Y. Han, H. Wang, “Surface integrity and removal mechanism in simulated dental finishing of a feldspathic porcelain", J. Biomed. Mater. Res. Part. B: Appl Biomater. 79B (2006) 365-378.

[13] F.X. Song, L. Yin, "Surface morphology and fracture in handpiece adjusting of a leucite-reinforced glass ceramic with coarse diamond burs", Mat. Sci. Eng. A. 534 (2012) 193-202. [14] R.G. Luthard, M. Holzhüter, H. Rudolph, V. Herold, M.H. Walter, "CAD/CAM-machining effects on Y-TZP zirconia", Dent. Mater. 20 (2004) 655-662.

[15] U. Lohbauer, F.A. Müller, A. Petschelt, "Influence of surface roughness on mechanical strength of resin composite versus glass ceramic materials", Dent. Mater. 24 (2008) 250256.

[16] Y. Nakamura, S. Hojo, H. Sato, "The effect of surface roughness on the Weibull distribution of porcelain strength", Dent. Mater. J. 1 (2010) 30-34.

[17] ISO 4287, "Geometrical product specifications (GPS), surface texture: profile method, terms, definitions and surface texture parameters", Int. Organ. Stand. (1997).

[18] S.B. Parra, C.R. Gennari, G.F. Melchiades, O.A. Bosch, "Rugosidade superficial de revestimentos cerâmicos", Cerâm. Ind. 11 (2006) 15-18.

[19] A.R. Machado, M.B. Da Silva, R.T. Coelho, A.M. Abrão, Teoria da Usinagem dos Materiais, $1^{\mathrm{a}}$ Ed., Blücher, S. Paulo, 2009.

[20] ISO 6872, "Dentistry - dental ceramics", Int. Organ. Stand. (2008).

[21] G.D. Quinn, Fractography of ceramic and glasses, U.S. Government Printing Office, Washington (2007).

[22] J.B. Wachtman Jr., W. Capps, J. Mandel, "Biaxial flexure tests of ceramic substrates", J. Mater. 7 (1972) 188-194.

[23] R. Kelly, Y.J. Yi, "Failure responses of a dental porcelain having three surface treatments under three stressing conditions", Dent. Mater. 27 (2011) 1252-1258. 
[24] S. Flury, A. Peutzfeldt, A. Lussi, "Influence of surface roughness on mechanical properties of two computer-aided design/computer-aided manufacturing (CAD/CAM) ceramic materials", Oper. Dent. 6 (2012) 617-624.

[25] H. Wang, M.N. Aboushelib, A.J. Feilzer, "Strength influencing variables on CAD/CAM zirconia frameworks", Dent. Mater. 5 (2008) 633-638.

[26] H. Fischer, M. Schäfer, R. Marx, "Effect of surface roughness on flexural strength of veneer ceramics", J. Dent. Res. 12 (2003) 972-975.

[27] D. Whitehouse, Surfaces and their Measurement, $7^{\text {th }}$ Ed., Hermes Penton Science Ldt, London (2002).

[28] A.R. Curtis, A.J. Wright, G.J. Fleming, "The influence of surface modification techniques on the performance of a Y-TZP dental ceramic", J. Dent. 3 (2006) 195-206.

(Rec. 26/09/2015, Rev. 06/11/2015, Ac. 18/11/2015) 